Al75 MO25 近傍の高分解能電子显微鏡観察

\title{
三井田陸郎 渡辺伝次郎(東北大・理)
}

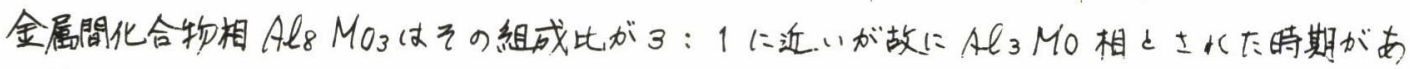
反。それが今のように呼ば北るメうになったのは1962年. Forsyth\& GranとPotaschke

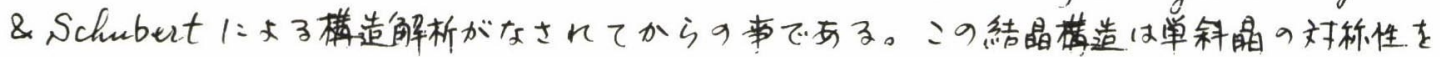

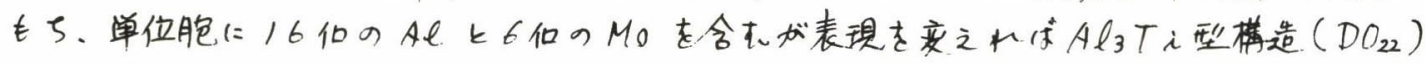

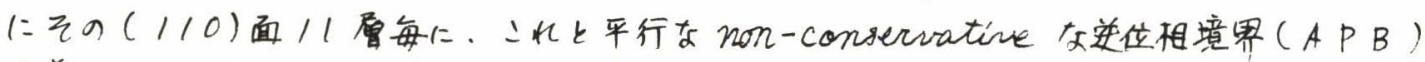

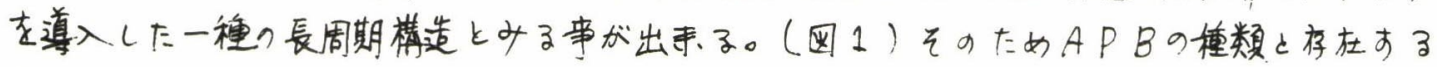
面によつてはもつと違つた组成比と梅造が考之られる筈である。我々及:のよつな结晶学舆

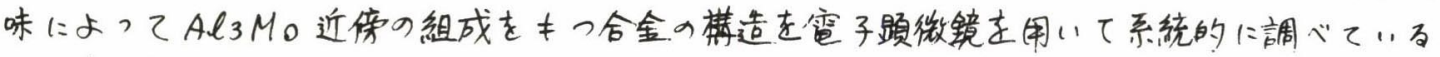

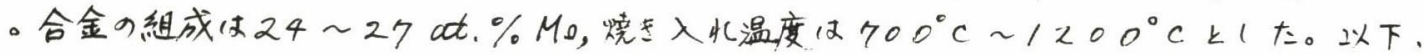
これまでに得られた結果を示しその棈造について考察を加える。

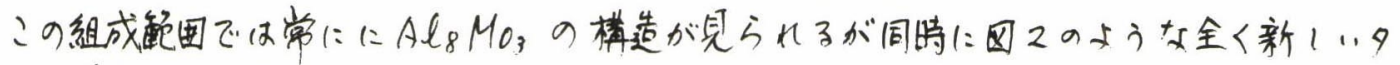

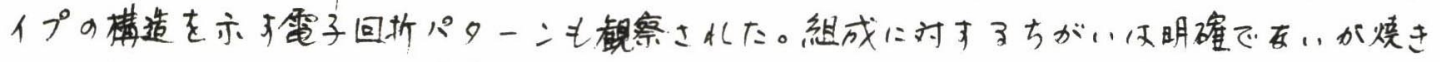

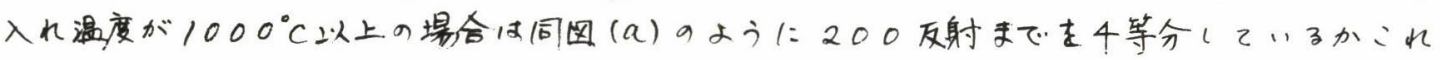

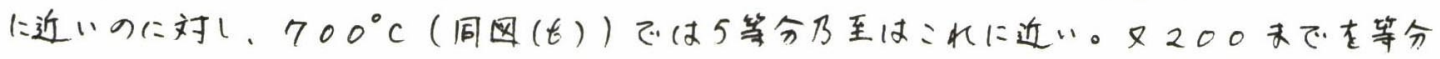

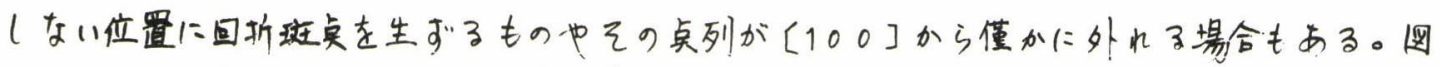

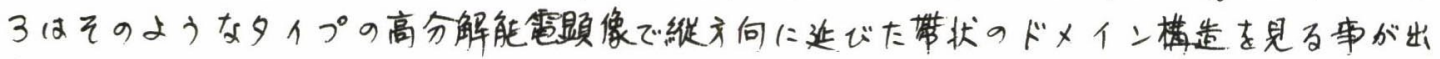
来る。このドメインはDO22 で楧成さ忆、隣合ったそれと位相がずれているのがかかる。A P B 9入方上間隔はいく分不规則であるが平均してみると（100）から僅かに倾いた面に

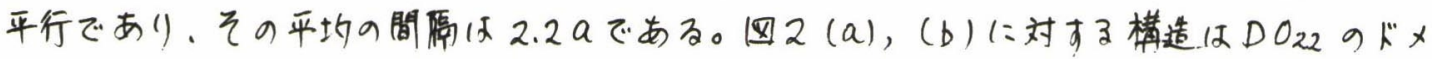
インが $x$ 方に各々2aと2.5aの間隔で(100)に平行なAPBを介(亚人でいるであ ろつ。その迹位相べクトル

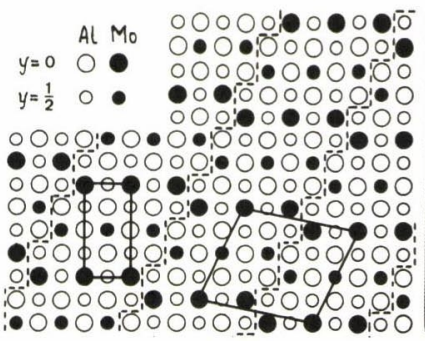

四1. $A 1.8 \mathrm{MO}_{3}$ 榙造, 点線1 $\mathrm{APB}$

を、長方形々平行四辺形12各《D $\mathrm{D}_{22}$ 櫣造上单位胞走示す。

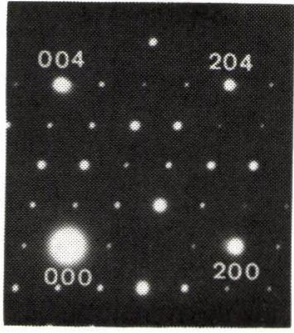

2 (a)

25 at. \% Mo $1000^{\circ} \mathrm{C}$

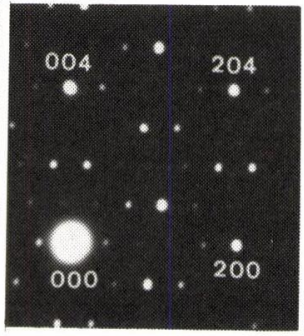

2 (b)

25 at $\%$ Mo $700^{\circ} \mathrm{C}$

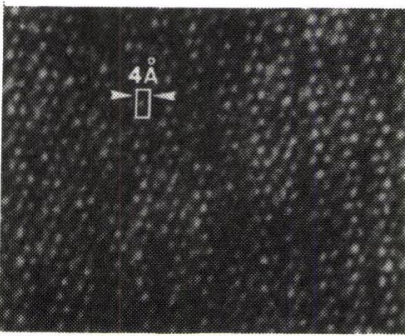

W. $25.5 \mathrm{at} \% \mathrm{MO}, 1100^{\circ} \mathrm{C}$ 白い長形形は D 22 模造走。 示す。 